\title{
Domestic violence against women, public policies and community health workers in Brazilian Primary Health Care
}

\author{
Violência doméstica contra mulheres, políticas públicas \\ e agentes comunitários de saúde na Atenção Primária Brasileira
}

Marcos Claudio Signorelli ${ }^{1}$

Angela Taft ${ }^{2}$

Pedro Paulo Gomes Pereira ${ }^{3}$

${ }^{1}$ Universidade Federal do Paraná. R. Jaguariaíva 512, Balneário de Caiobá. 83260-000 Matinhos PR Brasil.signorelli.marcos@ gmail.com

${ }^{2}$ La Trobe University.

Melbourne Australia.

${ }^{3}$ Universidade Federal de São Paulo. São Paulo SP Brasil.

\begin{abstract}
Domestic violence creates multiple harms for women's health and is a 'wicked problem' for health professionals and public health systems. Brazil recently approved public policies to manage and care for women victims of domestic violence. Facing these policies, this study aimed to explore how domestic violence against women is usually managed in Brazilian primary health care, by investigating a basic health unit and its family health strategy. We adopted qualitative ethnographic research methods with thematic analysis of emergent categories, interrogating data with gender theory and emergent Brazilian collective health theory. Field research was conducted in a local basic health unit and the territory for which it is responsible, in Southern Brazil. The study revealed: 1) a yawning gap between public health policies for domestic violence against women at the federal level and its practical application at local/decentralized levels, which can leave both professionals and women unsafe; 2) the key role of local community health workers, paraprofessional health promotion agents, who aim to promote dialogue between women experiencing violence, health care professionals and the health care system.

Key words Violence against women, Primary Health Care, Ethnography, Community health workers, Public policies
\end{abstract}

Resumo A violência doméstica (VD) cria múltiplos agravos à saúde das mulheres e é um desafio para profissionais e para os sistemas de saúde. O Brasil aprovou recentemente politicas públicas (PP) para manejo e cuidado de mulheres em situação de VD. Considerando essas PP, este estudo objetivou explorar como a VD contra mulheres é usualmente manejada na atenção primária à saúde brasileira, por meio da investigação de uma unidade básica de saúde e de sua estratégia de saúde da família. Foi adotada metodologia de pesquisa qualitativa de cunho etnográfico, com análise temática de categorias emergentes, interrogando os dados com teoria de gênero e com a produção teórica do campo da saúde coletiva brasileira. A pesquisa de campo foi conduzida em uma unidade básica de saúde e em seu território adscrito, localizado na região sul do Brasil. O estudo revelou: 1) um hiato entre PP direcionadas à VD contra mulheres implantadas a nível federal e sua aplicação prática a nível local/descentralizado, que pode deixar tanto profissionais quanto mulheres em risco; 2) o papel chave de agentes comunitários de saúde, profissionais de promoção da saúde, que objetivam promover o diálogo entre as mulheres experienciando violência, profissionais de saúde e o sistema de saúde.

Palavras-chave Violência contra a mulher, Atenção Primária à Saúde, Etnografia, Agentes comunitários de saúde, Políticas públicas 


\section{Introduction}

The World Health Organization (WHO) estimates that worldwide one in three women is or has been a victim of domestic violence (DV $)^{1}$, generating major challenges for health care systems. Multi-country studies ${ }^{2,3}$ have reported that this problem is more prevalent in low and middle income countries, with Brazil among this group.

DV results in significant harms to women's health ${ }^{4}$ and therefore many women seek care in the Brazilian Public Health System, named 'SUS' (Sistema Único de Saúde). But similar to women globally, because of the many known barriers to women's disclosure, they usually do not disclose the cause of their injuries ${ }^{5,6}$. Without training, neither do health care professionals (HCP) relate these observed symptoms to DV, which can include depression and trauma, among other physical, emotional and reproductive harms ${ }^{7,8}$.

To understand DV against women, the concept of gender is essential, referred in this article as described by Joan Scott ${ }^{9}$, who proposes gender as a constitutive element of social relationships built on perceived differences between the sexes, as a primary way to give meaning to relations of power.

From 2003 onwards, Brazil rolled out gender based public policies to manage women victims of DV in healthcare settings, highlighting the primary health care (PHC) system as an important context. The policies included: 1) the creation of the 'National Special Secretary for Women's Policies', responsible for developing intersectoral action plans focused on women, targeting particularly health, security, education and reduction of violence $^{10} ; 2$ ) the 'Maria da Penha Law' ${ }^{11}$, aiming to protect women, prevent, restrain, punish and eradicate VAW; 3 ) the 'National Policy to Combat VAW' $^{\prime 12}$, defining the ideal configuration of a network to support women; and finally, 4) the ' $\mathrm{Na}$ tional Policy for Humanization in Health ${ }^{13}$, not exclusive for VAW, but focused on humanization of all health care approaches.

These policies have been recently implemented into PHC settings within SUS through the Family Health Strategy (FHS), which covers more than $80 \%$ of municipal councils in Brazil. This is a decentralized and territorialized model of PHC, inspired by the Cuban Model of Family Doctors ${ }^{14}$. The strategy consists of a Basic Health Unit (BHU) and its specified territory, consisting of the PHC service center, composed of teams of HCPs and para-professionals responsible for a specific community. The teams include gener- al practitioners, nurses, allied professionals and also para-professionals, particularly a group of Community Health Workers $(\mathrm{CHW})^{15}$.

$\mathrm{CHW}$ are people usually from their respective local community, living in the neighborhood, who understand the community's specific characteristics. CHW are usually trained to identify and monitor common health conditions, visiting users' homes once a month, to explore the health conditions ${ }^{16,17}$. Cases which could require HCP attention are usually reported to nurses, who are responsible for professional home visits and if necessary, doctors can also be involved. CHW are considered the key to linking communities with health services, and are recognized as health educators who connect popular and scientific knowledge ${ }^{15}$.

Within the framework of these recent policies and practices, this study aimed through ethnographic qualitative research within one specific BHU to describe the intersections between federal policies, the SUS, and professionals who care for women living with DV in PHC settings.

\section{Methodology}

This study utilized ethnographic research methodology $^{18,19}$ as outlined by Geertz ${ }^{20}$. It aimed to understand the relationships between stated policies at the federal level and health care delivery at the local level, through para and health professionals' practice, behaviors and attitudes toward women experiencing DV in the PHC setting. The theoretical basis of gender and Brazilian collective health informed the design, conduct, analysis and synthesis of this study. We undertook triangulation, including document analysis, participant observation and in-depth interviews with key informants. We analyzed Brazilian federal policies addressing VAW, aiming to understand the intersections between such policies and its materialization in SUS.

The first author (MS) conducted a field study over seven months, between June/2009 and Jan/2010, at a BHU located in a small town on the South coast of Brazil. For ethical purposes, in this article we have de-identified both BHU and town. A BHU from an interior small town was chosen, because it is representative of the majority of the 5570 municipalities in Brazil. 88\% of Brazilian municipalities have up to 50,000 inhabitants $^{21}$. This specific BHU comprised a population of three districts/suburbs in an area covered by three FHS teams. Capitals and big cities usu- 
ally have more structured services to respond to abused women, but the goal of this study was to highlight what occurs in the peripheral/interior of the country. This region, like many other Brazilian areas, had no Specialized Police Offices for Women (Delegacia Especializada de Atendimento à Mulher - DEAM), which are common in big/ medium cities), nor referral centers for women's care. The DV reporting data requirements were also not implemented, despite recent laws mandating compulsory notification ${ }^{22}$ for HCPs who detect it.

MS had a previous link with this BHU, working weekly in collaboration since 2006, supervising health students from the local University for service training in PHC settings and he also participated as a councillor in the Municipal Health Council. During field research, MS was usually present 3 or 4 times per week in alternating periods, observing, interviewing and documenting the BHU's routine in his field diary.

Ethnographic research included discussions with many people during this field research, but in-depth interviews were specifically conducted with fifteen respondents: eight CHW, three nurses, two physiotherapists (allied professionals) and also with two women from the community, identified by respondents as victims of DV. All other BHU staff were also approached, including general practitioners, dentists, and six other CHW. However they were excluded as they could either not identify any cases of DV, or refused to participate in the study. The focus of this study was on professionals, so only two victims were interviewed, as this was not the goal of this research. Anonymity and confidentiality of all subjects were guaranteed and fully informed consent was negotiated. This study followed all ethical procedures and was approved by the Ethics Committee from Universidade Federal de São Paulo.

The in-depth interviews were recorded, transcribed, coded and thematic analysis of these and the field notes was conducted with categories emerging from the field. The set of emergent data were also interrogated with gender theor $y^{9,23}$ and Brazilian collective health theory ${ }^{24-27}$.The analysis and commentary in this article are from the authors' standpoints as both advocates for women rights and academics.

\section{Results and discussion}

\section{Describing the ethnographic field}

The field study area is one of the least developed regions of Southern Brazil and it represents a typical Brazilian interior/inland, characterized by small towns deprived of decent infrastructure and where a considerable part of the country's population lives. The town focused in this research is a summer resort, with approximately 30,000 inhabitants ${ }^{21}$, that increases tenfold during the summer season. The BHU comprises two distinct territories: a seaside town, where wealthy families have vacation residences and which is desolate in the summer off-season; and a popular neighborhood, including a poor squatting population who work for those who come to spend vacation at the resort. In this neighborhood, most streets have no pavement, lack sanitation, have irregular electrical connections and there are many makeshift houses. As in other Brazilian regions and worldwide, in socially unequal conditions with seasonal unemployment and gender inequality, DV against women is a common significant phenomenon. This city has no specific health services for the support of victims or to prevent DV. Even the regional pole city, with almost 150.000 inhabitants ${ }^{21}$ does not have one, neither a DEAM, despite this city having recently implemented its Municipal Nucleus for Violence Prevention and Promotion of Peace's Culture. Nucleus strategies are focused mainly on integrating different sectors and education/ campaigns to prevent violence. However the actions of this Nucleus are restricted to the regional pole city, so the regionalized network proposed by SUS is also incomplete in this area and needs to overcome gaps towards the integration of care. In the researched city, the actions were restricted to Social Assistance after DV, and nevertheless limited to more severe episodes. These observations provide evidence of the limit of the National Policy to Combat VAW'12 implementation at local levels, which proposes intersectoral collaboration involving health, social assistance, public security, and education, among others.

\section{DV against women: detection by $\mathrm{CHW}$ and disclosure}

One of the main goals of federal policies ${ }^{11,12}$ is to improve the detection of DVAW in healthcare settings so as to consequently plan and intervene. We grouped the detection of DV cases that 
emerged from this community into two distinct DV categories: 'acute circumstances' and 'chronic conditions'. 'Acute circumstances' were recent occurrences that briefly arose at SUS or occurred during home visits and were witnessed by members of the FHS teams.

In acute circumstances, health problems were related to recent violent acts usually associated with physical and/or sexual injuries. According to HCPs, women experiencing acute DV often presented with visible physical signs and frequently sought care at emergency services, such as first aid departments and/or hospitals, thus, outside the domain of PHC. However, in some cases, providers also revealed that through the FHS model professionals became aware of acute injuries, especially when they visited patients' homes.

However, victimized women could develop 'chronic conditions' due to the repeated DV effects in their lives. They frequently attended health services, but mostly did not disclose DV nor consider themselves as victims. They generally dropped hints. In PHC they presented routinely through consultations with doctors and nurses at the BHU and/or they were visited by workers from FHS, including CHW.

In this BHU, each CHW cared for 130 to 200 families, which is a heavy caseload. As CHW lived and worked in their respective communities, constantly visiting the families under their care, they knew everyone by name. They knew the composition of families, social and health conditions and most people treated them like a family friend. It was common that CHW listened to many demands and helped people seek responses with a wide range of issues, such as helping workers to organize documents to retire and disclosure of intimate problems, such as DV. This was the case of Ms. Marlene, 65 years old, married and living with DV for 40 years. She disclosed to her CHW:

He has hit me many times. He had left my arm purple. And he even [put] my column [spine] out of place [...] When I went to the hospital at that time, I said I had fallen down the stairs. [...] They sent me back home, but the pain continued for many days, it was unsupportable and I had to seek help. The only person from SUS that I told the truth was [to] Monica, my CHW, because I trust her. She helped me to schedule appointments with [the] doctor and physiotherapist, to treat my pain. She also helped me to cope with the problem, because sometimes, the blow's pain passes, but the pain caused by the words... sometimes it's worse. (Ms Marlene, BHU user).
Ms. Marlene, like many women victims of DV, did not expose the cause of the symptoms at the hospital, as visits to acute care are marked by shorter relationships with HCPs. However, in the PHC, with the opportunities provided by regular home visits and when women trusted their caregivers, many women tended to disclose. This was better illustrated by her CHW: Ms Marlene is one of the many women who disclosed private issues for me. I think these women like to share their stories with others... they like someone to listen to their problems. And that's why we are here. (Monica, CHW).

HCPs have an essential role in primary prevention, early identification and intervention in cases of DV as recently recommended by the $\mathrm{WHO}^{28}$. However, not all HCPs are aware of it, as Sonia, a CHW perceived:

The woman [victim of DV] has always a problem. And they cannot figure it out. She goes to the doctor, make exams, back to the BHU, take medicines, forwards forth, back and forwards ... and HCPs simply do not discover it. A[fter a] long time, we [CHW], who are attending her house, we discover that she has family problems, violence! And that it causes diseases to her. And HCPs, I saw that they don't have the ability to perceive it and meet that woman's needs. (Sonia, CHW)

Some HCPs from that BHU, especially doctors, conducted unnecessary examinations with inconclusive data, categorized the findings as 'diffuse complaints' and did not detect the problem. Many authors ${ }^{29,30}$ have reported that health professionals have difficulties managing DV. Warshaw $^{30}$ has long argued that professionals must expand the traditional model of management and training, arguing for personal sensitivity, modelling non-violent behavior and social commitment.

Many narratives from different CHW like Sonia highlighted the role that local para-professionals can play as a key element, detecting and promoting links between women victims of DV and SUS, a fact also suggested by other recent studies $^{31}$. We found a common pattern in that community:

1) CHW knew about DV directly from the woman's disclosure or frequently from neighbors;

2) CHW reported it to the nurses;

3) Depending on the nurse's personal sensitivity (not based on policies or institutionalized in SUS), she could:

a) approach women, assessing their primary needs and providing them information; or 
b) neglect the issue and treat it as part of a health problem;

4) If necessary, she might refer the woman to doctors (usually when there are physical injuries) and/or allied HCPs (psychologists, physiotherapists, social workers, etc.).

\section{FHS teams, safety and family violence}

DV is not only physical aggression. [It is] psychological also, isn't? Psychological aggression, to treat bad, to cuss... If you forbid, if you inhibit to do something that you don't agree [...] threaten. I think it is very psychological. (Margit, CHW).

Many studies have shown that HCPs do not receive adequate training to deal with $\mathrm{DV}^{30,32}$, despite it being a goal mentioned in many of the federal policies. Members of that FHS team, except for one nurse, reported that they were not trained to care for women victims. The $\mathrm{WHO}^{28}$ and recent Brazilian policies have recently argued the need for HCPs to be supported at many more levels, by structures of the system itself, guidelines, funding and resources. However, despite gaps in their training, many professionals at the BHU illustrated attentiveness to psychosocial implications of violence and to women's welfare, an important issue outlined in the 'National Policy to Combat VAW'12. DV against women was perceived comprehensively by most professionals we interviewed. However, without the system's effective support, their approaches were timid and not institutionalized.

The recent policies ${ }^{11,12}$ are based on a gendered perspective. Although $\mathrm{HCPs} / \mathrm{CHW}$ did not theorize about gender, they highlighted perceived differences between men and women in that community:

Many husbands exploit women. There are husbands that arrive [at home], take the shoes off, sit down on the sofa and say: give me a glass of water, give me a plate of food... So, for me [violence] it's all this set. Not necessarily to beat [the woman]. (Cleide, CHW).

Members of the FHS team articulated that DV against women was committed not only by intimate partners, but also by sons/grandsons and father/stepfathers almost as frequently as that practiced by partners. This suggests a gendered perspective, although neither gender category, nor consequences from its inequalities were mentioned. Respondents also highlighted not only common cases of family violence but also the intergenerational spread of violence, like Nurse Helga who reported a case involving a 15 years old girl: 'the stepfather had sexual relations with mother and stepdaughter'. Nurse Helga, talked about perceived marks on children's bodies, suggesting child abuse. According to Helga, the HCPs' strategy was not to report the abuse directly to authorities, because they could be targeted and consequently become victims. In a previous case described by her, a situation involving child sexual abuse was reported by a CHW to the Municipal Guardian Council (as mandatory on policies), but the CHW's identity was revealed. She subsequently began to suffer threats from the aggressor. The nurse spoke of a planned strategy to meet children, together with CHW, psychologist and social assistance and involving neighbors/community during visits, to galvanize the community to help report cases to the Guardian Council. Working in such a collaborative network is one of the goals argued by the 'National Policy to Combat VAW'12 as a possibility to prevent/reduce DV.

It is important to recognize the possibilities, limits and especially risks for FHS teams facing such complex situations. During field research we observed episodes involving risks to workers' own safety, with scarce support from the distant federal health system. Beyond risks during home visits, many workers revealed urban violence and negotiations with drug dealers, which was a fundamental issue in accessing some territories. Other studies provide evidence of the challenges faced by FHS teams, including: precarious working conditions associated with highly stressful and debilitating illnesses ${ }^{33}$; for which CHWs do not feel prepared to provide adequate care ${ }^{34}$; and receiving low salaries, work overload and lack of training and appropriate qualifications ${ }^{35}$.

\section{Mind the gap - the distance between theories, policies and practices}

Humanized approaches are one of the objectives of the 'National Policy to Combat VAW'12. The National Policy for Humanization in Health ${ }^{13}$ describes a Brazilian strategy that can be particularly important to victims of DV. It promotes 'acolhimento', a Portuguese term without an equivalent strict translation to English, sometimes translated as 'user embrace' or 'receptivity', but that we will try to summarize based on Brazilian collective health studies and illustrated with data from this field research. This concept can be likened to patient-centered care, involving shared decision making. 'Acolhimento' is sensitive to patients' problems, and identifies the op- 
timum forms of communication to be used with individual patients in clinical settings. In the context of communication, 'acolhimento' could be better translated as care-oriented-communication. Some Brazilian authors ${ }^{24,26,27,36,37}$ point to 'acolhimento' as a possibility for enhancing health care, which would be highly appropriate for caring for women victims of DV. 'Acolhimento' is a technique to humanize health care and consists of the promotion of a more meaningful dialogue between workers and users ${ }^{38}$. The concept of 'acolhimento' is challenging and requires more reflection, both conceptual and empirical, about its strengths and limitations.

Oliveira et al. ${ }^{26}$ demonstrates aspects of 'acolhimento' from referral services for women who suffered sexual violence in São Paulo. They describe it as a relationship of solidarity, a respectful and welcoming one between professionals/ para-professionals and health services in a holistic relationship with users. Based on these meanings of 'acolhimento', it is possible to illustrate it from an incident narrated by Carminha, a 26 year old physiotherapist, working for two years at the BHU, during her home visit:

A lady was often beaten by her son, a drug user. In one occasion I was at her house, caring [for] her bedridden husband and her son threatened her with a knife. I had to go over it with my clipboard, which was the only thing I had in my hand. The woman was behind me. So I was between the abuser and the abused. If I hadn't done that, I think he would have killed her [...] I took the case to the mayor. He was arrested. [...] I sent her [unofficially, but for friendship] to a health team with social worker, nurse, psychologist and also her CHW. We used to go together to care [for] her. I helped her to take care of her self-esteem, I took her lipstick and makeup. We also encouraged her to think more positively about herself, about her welfare. (Carminha, physiotherapist).

This case is illustrative of 'acolhimento', because, according to the literature, the physiotherapist, initially was only responsible to care for the husband. However after perceiving a DV situation, extended her focus to care also for the woman. In this case, it highlights 'universal accessibility', one of 'acolhimento's' characteristics $^{39}$ which consists of expanding care to those who may not demand it spontaneously, for fear/ shame, as previously explained. The narrative extends a 'patient-centred care' approach, as the woman was not her initial patient, to another characteristic argued by the authors, in her support for the woman's other needs: her self-es- teem, relationships and social life. Carminha also urged the involvement of an inter-professional team to work together, focused on the woman, with the participation of an allied HCP team and including paraprofessional help. Thus, 'acolhimento' assumes the establishment of multi-disciplinary collaboration, a centrality on people (not on procedures) - particularly on users - and a focus well beyond biological issues, considering the psychosocial complexity of people. We observed this interdisciplinary approach was not fully institutionalized at SUS in that BHU. Those PHC professionals were not specifically trained for it, despite the stated policies. Their knowledge about 'acolhimento' was based on common sense and empathy. This case exemplifies the current practice that referrals between HCPs are mostly based on informal relationships and not through an established protocol or formal routine.

\section{Challenges to implement policies into PHC}

Silva-Júnior ${ }^{40}$ also warns us about some HCPs' difficulty in dealing with users' sufferings. They suggest that the idea of referring people to other professionals (experts) transfers the responsibility for care. The effort to establish a common focus, based on dialogue between users and professionals is a challenge, consistent with our experience, as mentioned by nurse Betina, head of the BHU:

I think who should be more involved [with DV] would be the social worker, right? It is the function of social workers. We follow together, of course. To check when there [is] maltreatment. But I think the intervention... the first would be with the social worker. It is their function. Because we are directed to health, right? (Betina, nurse)

Whilst this is gradually changing, for some HCPs in Brazil as in most countries, DV is not a health problem. It is a challenge to put this problem into the health agenda, because how will women be supported appropriately if only some HCPs understand their problem as a health issue? Humanization presupposes solidarity, listening to users' requests, recognizing their needs and assuming attitudes capable of receiving (welcoming), listening and giving appropriate responses. It implies providing assistance with problem solving, directing when appropriate to other health services for continuity of care, establishing linkages with these services to ensure the effectiveness of referrals ${ }^{41}$. It's not just about referral, passing the problem ahead, but it involves following the referral process, guaranteeing that 
referrals are really focused on user's needs and helping them to solve their problems, in partnership with other professionals.

The majority in this BHU saw beyond a women's biological symptoms, such as the case described by the physiotherapist Carminha. But when the system does not support them, they can often suffer, along with the women. Illustrating this, Sonia, a CHW added:

There was a woman who gave birth to a baby and she went home. Her husband was a drug user, he was addicted to crack. They had two other children, and he was beating her, he even locked her inside the house. I went to the nurse and we took her away. We took her to a hotel until she gets a home. Later, she got a home, she got job. We helped her with food. We bought a food basket for her. We found a small hotel for her, to stay with kids [...] We paid, with our [own] money. (Sonia, CHW)

For the CHW and nurse to protect the woman and ensure her and her children's safety they had to reach into their own pockets because there was an inadequate infrastructure to support them. To obtain financial support from Brazilian social service agencies is a very bureaucratic process, which could take several weeks to collect all the documents required to prove her financial needs. Therefore, the implementation of the 'National Policy to Combat VAW'12 should be observed with caution: while it recommends detection and prevention of DV against women in health care networks as a general guideline, there is very little support structure to help professionals materialize it.

The outcomes may depend substantially on negotiated actions between professionals and users, which in Brazil's PHC is done initially mostly by CHW during home visits. This is considered the 'initial gate' to the system. Depending on this initial approach, if women are not decently treated, many of them do not continue in the system, or seek public health services again.

Despite an 'acolhimento' strategy not having been officially implemented in the municipality, as advocated in the National Policy for Humanization in Health ${ }^{13}$, through this ethnography we observed that many workers from that BHU guided their relations with women victims of DV on assumptions of this policy: establishing dialogues and actively seeking the problem, even without a decent structure within which to conduct it.

\section{Final considerations - $\mathrm{CHW}$ and 'Acolhimento': Two Brazilian federal policies for re-thinking the care of DV victimized women}

We highlight from this ethnography: some gaps (and also some possibilities) between Brazilian public policies and its implementation in locally relevant PHC services and the potential key role of CHW in providing care for women experiencing DV. CHW constantly visit people under their care, entering the domestic space, so dialogue can be established spontaneously and horizontally though not always easily. It is important, but may also be problematic, that $\mathrm{CHW}$ belong to their respective communities, which facilitates the establishment of more empathic relations and minimizes the asymmetric power issues that traditionally exist between HCP and users. However, their familiarity may be also a risk for some women experiencing DV because of their need for confidentiality, as the ethical issues implies in their work as CHW. Some users may perceive their involvement as statesanctioned surveillance with implications again for CHW safety.

We highlight that collaboration between HCP and CHW through FHS can be crucial for caring women victims of DV. CHW together with HCPs can potentially and effectively care for cases of violence, because during home visits they can be present, with families and communities, identifying cases of DV. However, we highlight that CHW cannot work in isolation. Working with HCPs as teams can be a significant collaboration for dealing with DV. There is a greater visibility to the role of the FHS teams since, in most cases, women report to them issues that they would not disclose to other professionals.

Better training of CHW and HCP should be an important priority to translate the above mentioned public policies into practice, because recognition of violence requires a high degree of awareness, sensitivity, consciousness of safety and confidentiality for both woman and workers. FHS teams must be equipped with knowledge in order to deconstruct situations and encourage/ provide support and resources to act. Actions should include appropriate training for 'acolhimento', which could has the potential to put $\mathrm{Hu}$ manization policy into practice to better manage DV. Therefore, this ethnography has demonstrated that CHW and also HCP are relevant co-participants in the process of care of women victims of DV and can play a significant role in 'acolhi- 
mento' This Brazilian experience may constitute a key strategy to support women affected by DV, both in chronic and acute situations. Theoretically, such considerations seem reasonable, but in practice enormous challenges and gaps between discourses and practices still persist. Gaps in training/awareness about 'acolhimento' intersect with lack of effective strategies for combat- ing unequal gender relations. All these initiatives require the overall system's supportive structure and a greater attentiveness to the potential exposure and harm that professionals are subject to. Thus, listening to professionals and para-professionals, who are in direct contact with women victims of $\mathrm{DV}$, is essential to illuminate theory, policies and practices.

\section{Collaborations}

MC Signorelli contributed in the idealization, design, field research and writing. A Taft and PPG Pereira contributed in the idealization, design and writing.

\section{Acknowledgements}

CAPES Brazilian Foundation for the scholarship. 


\section{References}

1. Krug EG, Mercy JA, Dahlberg LL, Zwi AB. The world report on violence and health. Lancet 2002; 360(9339):1083-1088.

2. Garcia-Moreno C, Jansen HAFM, Ellsberg M, Heise $\mathrm{L}$, Watts $\mathrm{CH}$. Prevalence of intimate partner violence: findings from the WHO multi-country study on women's health and domestic violence. Lancet 2006 368(9543):1260-1269.

3. Schraiber LB, D'Oliveira AFPL, França-Junior I, Diniz SC, Portella AP, Ludermir AB, Valença O, Couto MT. Prevalência da violência contra a mulher por parceiro íntimo em regiões do Brasil. Rev Saude Publ 2007; 41(5):797-807.

4. World Health Organization (WHO). Global and regional estimates of violence against women: prevalence and health effects of intimate partner violence and non-partner sexual violence. Geneva: WHO; 2013.

5. Andersson N, Cockcroft A, Ansari U, Omer K, Ansari NM, Khan A, Chaudhry UU. Barriers to disclosing and reporting violence among women in Pakistan: findings from a national household survey and focus group discussions. J Interpers Violence 2010; 25(11):1965-1985.

6. Petersen R, Moracco KE, Goldstein KM, Clark KA. Moving beyond disclosure: women's perspectives on barriers and motivators to seeking assistance for intimate partner violence. Women Health 2004; 40(3):6376.

7. Abramsky T, Watts CH, Garcia-Moreno C, Devries K, Kiss L, Ellsberg M, Jansen HA, Heise L. What factors are associated with recent intimate partner violence? findings from the WHO multi-country study on women's health and domestic violence. BMC Public Health 2011; 11:109.

8. Ellsberg M, Jansen HA, Heise L, Watts $\mathrm{CH}$, Garcia-Moreno C; WHO Multi-country Study on Women's Health and Domestic Violence against Women Study Team. Intimate partner violence and women's physical and mental health in the WHO multi-country study on women's health and domestic violence: an observational study. Lancet 2008; 371(9619): 1165-1172.

9. Scott J. Gender: a useful category of historical analysis. The American Historical Review 1986; 91(5):1053-1075.

10. Brasil. Lei no 10.683 de 28 de maio de 2003. Dispõe sobre a organização da Presidência da República e dos Ministérios, e dá outras providências. Diário Oficial da União 2003; 28 maio.

11. Brasil. Lei no 11.340 de 7 de agosto de 2006. Cria mecanismos para coibir a violência doméstica e familiar contra a mulher e dá outras providências. Diário Oficial da União 2006; 7 ago.

12. Brasil. Secretaria de Políticas para as Mulheres/Presidência da República (SPM/PR). Política Nacional de Enfrentamento à Violência Contra as Mulheres. Brasília: SPM/PR; 2011.

13. Brasil. Ministério da Saúde (MS). Política Nacional de Humanização: a humanização como eixo norteador das práticas de atenção e gestão em todas as instâncias do SUS. Brasília: MS; 2004

14. Brasil. Ministério da Saúde (MS). Saúde da Família: uma estratégia para a reorientação do modelo assistencial. Brasília: MS;1997.
15. Zanchetta MS, Kolawole Salami B, Perreault M, Leite LC Scientific and popular health knowledge in the education work of community health agents in Rio de Janeiro shantytowns. Health Educ Res 2012; 27(4):608-623.

16. Gogia S, Sachdev HS. Home visits by community health workers to prevent neonatal deaths in developing countries: a systematic review. Bull World Health Organ 2010; 88(9):658-666B.

17. Zanchetta MS, Meireles Pinto R, Galhego-Garcia W, Cunha Z, Cordeiro HA, Fagundes-Filho FE, Pinho MA, Voet SM, Talbot Y, Caldas RS, Souza TJ. Brazilian community health agents and qualitative primary healthcare information. Prim Health Care Res Dev 2015; 16(3):235-245.

18. Emerson RM, Fretz RI, Shaw LL. Writing ethnographic fieldnotes. Chicago: University of Chicago Press; 1995.

19. Liamputtong P, Ezzy D. Qualitative Research Methods. Melbourne: Oxford; 2005.

20. Geertz C. The interpretation of cultures. New York: Basic Books; 1973.

21. Instituto Brasileiro de Geografia e Estatística (IBGE). Estimativas de população para $1^{\circ}$ de julho de 2013. Brasília: IBGE; 2013.

22. Brasil. Lei no 10.778 de 24 de novembro de 2003. Estabelece a notificação compulsória, no território nacional, do caso de violência contra a mulher que for atendida em serviços de saúde públicos ou privados. Diário Oficial da União 2003; 24 nov.

23. Delphy C. Close to home: a materialist analysis of women's opression. London: Hutchinson; 1984.

24. Gomes MCPA, Pinheiro R. Acolhimento e vínculo: práticas de integralidade na gestão do cuidado em saúde em grandes centros urbanos. Interface (Botucatu) 2005; 9(17):287-301.

25. Nunes MO, Trad LB, Almeida BA, Homem CR, Melo MCIC. O agente comunitário de saúde: construção da identidade desse personagem híbrido e polifônico. Cad Saude Publica 2002; 18(6):1639-1646.

26. Oliveira EM, Barbosa RM, Moura AAVM, Kossel K, Morelli K, Botelho LFF, Stoianov M. Atendimento às mulheres vítimas de violência sexual: um estudo qualitativo. Rev Saude Publ 2005; 39(3):376-382.

27. Teixeira RR. O acolhimento num serviço de saúde entendido como uma rede de conversações. In: Pinheiro RE, Mattos RA, organizadores. Construção da integralidade: cotidiano, saberes e práticas em saúde. Rio de Janeiro: UERJ/IMS, Abrasco; 2003. p. 89-111.

28. World Health Organization (WHO). Responding to intimate partner violence and sexual violence against women: WHO clinical and policy guidelines. Geneva: WHO; 2013.

29. Freund KM, Bak SM, Blackhall L. Identifying domestic violence in primary care practice. J Gen Intern Med 1996; 11(1):44-46.

30. Warshaw C. Domestic violence: changing theory, changing practice. I Am Med Womens Assoc 1996; 51(3):87-91.

31. Fonseca RM, Leal AE, Skubs T, Guedes RN, Egry EY. Domestic violence against women from the perspective of the community health agent. Rev Lat Am Enfermagem 2009; 17(6):974-980. 
32. Alpert EJ. Violence in intimate relationships and the practicing internist: new "disease" or new agenda? Ann Intern Med 1995; 123(10):774-781.

33. Shimizu HE, Carvalho Junior DA. The working process in the Family Health Strategy and its repercussions on the health-disease process. Cien Saude Colet 2012; 17(9):2405-2414.

34. Waidman MA, Costa B, Paiano M. Community Health Agents' perceptions and practice in mental health. Rev Esc Enferm USP 2012; 46(5):1170-1177.

35. Costa MC, Silva EB, Jahn AOC, Resta DG, Colom IC, Carli R. Work process of community health agents: possibilities and limits. Rev Gaucha Enferm 2012; 33(3):134-140.

36. Ramos DD, Lima MA. Health care access and receptivity to users in a unit in Porto Alegre, Rio Grande do Sul, Brazil. Cad Saude Publica 2003; 19(1):27-34.

37. Silva-Júnior AG, Merhy EE, Carvalho LC. Refletindo sobre o ato de cuidar da saúde. In: Pinheiro R, Mattos RA, organizadores. Construção da integralidade: cotidiano, saberes e práticas em saúde. Rio de Janeiro: UERJ/IMS, Abrasco; 2003. p. 113-128.

38. Ayres JRCM. O cuidado, os modos de ser (do) humano e as práticas de saúde. Saúde e Soc 2004; 13(3):16-29.

39. Franco TB, Bueno WS, Merhy EE. O acolhimento e os processos de trabalho em saúde: o caso de Betim, Minas Gerais, Brasil. Cad Saude Publica 1999; 15(2):345-353.

40. Silva-Júnior AG. Lógicas de programar ações de saúde. In: Barboza PR, organizador. Curso de especialização autogestão em saúde: guia do aluno. Rio de Janeiro: Fundação Oswaldo Cruz; 2001. p. 81-107.

41. Brasil. Ministério da Saúde (MS). HumanizaSUS: acolhimento com avaliação e classificação de risco: um paradigma ético-estético no fazer em saúde. Brasília: MS; 2004.

Artigo apresentado em 28/08/2015

Aprovado em 16/12/2015

Versão final apresentada em 18/12/2015 